\title{
EHMTI-0166. Chronic daily headace-impact of adverse childhood experiences
}

\author{
M Bøe*, ET Thortveit, A Vatne, I Frøytland, LK Kjellevold, K Stø, A Mygland \\ From 4th European Headache and Migraine Trust International Congress: EHMTIC 2014 \\ Copenhagen, Denmark. 18-21 September 2014
}

\section{Background}

In "Kronhodestudien" (KS) published in 2007-2009 we followed a cohort of 80 patients with chronic daily headache one year after withdrawal therapy and found that headache improved by $>50 \%$ in a third, and a third did not improve [1].

\section{Aim}

To examine whether adverse childhood events is associated with chronic headache and prognosis after withdrawal therapy.

\section{Method}

All 80 patients from the KS study were invited to a follow-up in 2013. Headache was registered, and a questionnaire concerning Adverse Childhood Events (ACE) was delivered to KS patients and controls without headache or other chronic pain. The study was performed anonymously and approved by the ethical committee.

\section{Results}

Sixty-six KS patients (73\% women) and 69 controls (70\% women) were included. Total ACE score was higher in patients [1.6 (1.1-2.1)] than in controls [0.9 (0.5-1.3)], $\mathrm{p}=0.02$. Reporting sexual violation was more common in patients without improvement of headache [9/24 (38\%)] than in controls [7/69 (10\%)], p <0.01. An ACE score > 4 was more common in patients who did not improve [7/24 (29\%)] than in patients who had improved more that $50 \%[1 / 21(5 \%), \mathrm{p} 0.05]$, and more common than in controls [8/69(12\%), $\mathrm{p}=0.04]$.

\section{Conclusion}

Adverse childhood experience seems to be more common in patients with chronic headache than in controls,

Neurological Department, Sørlandet hospital Kristiansand, Kristiansand, Norway

(c) 2014 Bøe et al; licensee Springer. This is an Open Access article distributed under the terms of the Creative Commons Attribution License (http://creativecommons.org/licenses/by/2.0), which permits unrestricted use, distribution, and reproduction in any medium, provided the original work is properly cited. and most common in patients with a poor response to withdrawal therapy.

No conflict of interest.

Published: 18 September 2014

\section{Reference}

1. Bøe MG, Salvesen R, Mygland A: Chronic daily headache with medication overuse: predictors of outcome 1 year after withdrawal therapy. Eur J Neurol 2009, 16(6):705-12.

\section{doi:10.1186/1129-2377-15-S1-D2}

Cite this article as: Bøe et al.: EHMTI-0166. Chronic daily headaceimpact of adverse childhood experiences. The Journal of Headache and Pain 2014 15(Suppl 1):D2.

\section{Submit your manuscript to a SpringerOpen ${ }^{\odot}$ journal and benefit from: \\ - Convenient online submission \\ - Rigorous peer review \\ - Immediate publication on acceptance \\ - Open access: articles freely available online \\ - High visibility within the field \\ - Retaining the copyright to your article}

